Article

\title{
The Future of Extinction: William S. Burroughs' The Western Lands
}

\author{
Steen Ledet Christiansen \\ Department of Culture and Learning, Aalborg University, 9220 Aalborg, Denmark; steen@hum.aau.dk
}

Received: 28 September 2020; Accepted: 25 November 2020; Published: 8 December 2020

\begin{abstract}
In this article, I draw on William S. Burroughs' The Western Lands to think about what François Laruelle has termed a "generic humanity." This generic humanity broadens and expands our ethical obligations towards those who have not yet been included in humanity. Burroughs' emphasis in the novel on flattened time, magic, and death as transformation is used to show how we can make Mankind extinct from our way of thinking. Burroughs' novel is thus an example of a "philo-fiction," a work of literature that allows us to see the world differently.
\end{abstract}

Keywords: Beat Generation; William S. Burroughs; climate change; environmental humanities; posthuman; non-philosophy

\section{Introduction}

How can we think about the extinction of mankind? Living through the sixth mass extinction event, sometimes called the Holocene or Anthropocene extinction, this question seems not only pertinent but one of the few questions that truly matter. Nick Bostrom calls the looming collapse an "existential risk" - a risk that threatens the future of humanity. ${ }^{1}$ Yet the vastness of the Anthropocene extinction involves more than just Homo sapiens and Bostrom's anthropocentric survival guides perceive us as the pinnacle species, ripe for technological uplift into a more perfect posthuman species. ${ }^{2}$ However, humanity exerting dominance over the planet is the reason the Anthropocene is unfolding, revealing that mankind does not have authority over nature. A different way of thinking about humanity is needed; a way that not only decenters humanity but also expands the idea of humanity to be more inclusive. François Laruelle proposes the term "generic humanity" to suggest a universal but limited conception of humanity that is not "the tip or expression of the absolute." 3 That is to say, generic humanity is not dominant, not the pinnacle of evolution, but embroiled in a wider meshwork of nature. One writer who has done much to flatten and transmute the idea of the human species is William S. Burroughs.

Throughout his career, Burroughs was interested in what the human species is and rarely regarded the human species in a particularly favorable light. Burroughs insisted early on, in an infamous quote in a letter to Allen Ginsberg, that "human, Allan, is an adjective, and its use as a noun is in itself regrettable". ${ }^{4}$ Even at this early point in his writings, before any of his major works, Burroughs viewed humanity with suspicion and regret. We should note, however, that Burroughs does not dismiss the human species but rather diminishes the significance it has. To say that the human is an adjective and not a noun signals that Burroughs does not regard Homo sapiens as a stable entity in the world but

\footnotetext{
(Bostrom 2013).

(Bostrom 2009, pp. 186-215).

(Smith 2013).

(Burroughs 1993, p. 68).
} 
rather a relation in a larger ecological system. Humanity is a modifier, which is inherently different from conventional conceptions of humanity as an object in the world. Burroughs' writings may then serve as a shock to thought to force us to think about current times differently. This is needed, simply because what we are doing now is not working. Humanity certainly does modify the relations in which we exist. What matters is to understand more fully the consequences.

Let us take Burroughs at his word when he says that the "human problem cannot be solved in human terms". ${ }^{5}$ Burroughs clearly has no use for the idea of the human as pinnacle, either: "For Man is indeed the final product. Not because homo sap is the apogee of perfection, before which God himself gasps in awe-_I can do nothing more!"-but because Man is an unsuccessful experiment, caught in a biologic dead end and inexorably headed for extinction." ${ }^{6}$ Burroughs' writing has consistently been an attempt at thinking outside of the human, to understand that which is not human or, put differently, that which is nonhuman. In this way, I am less interested in what Burroughs' writings mean (always a notorious problem, anyway). What I am interested in is the ways in which Burroughs' writing can make us think differently about humanity. This is a topic that radiates throughout all of Burroughs' writings: from Naked Lunch and onward. Naked Lunch: "The broken image of Man moves in minute by minute and cell by cell ... Poverty, hatred, war, police-criminals, bureaucracy, insanity, all symptoms of The Human Virus. The Human Virus can now be isolated and treated."7 The Ticket That Exploded: "The human sickness is a complex of several virus strains". "Ten Years and a Billion Dollars": "the Word is literally a virus, and that it has not been recognized as such because it has achieved a state of relatively stable symbiosis with its human host". ${ }^{9}$ And so on, up to The Western Lands: "The human mold is broken and this you gotta hear ... out crawls a monster centipede" ${ }^{10}$ The reason for these pull-quotes is to show the line running through all of Burroughs' writings, whether fiction or nonfiction. A full discussion of Burroughs' interest in the human species both as a virus and one half of a virus, a malleable material that constantly transforms, is too large for this current article. Yet it is evident that the human species is a running concern for Burroughs. This is one reason why Burroughs has been considered a posthumanist writer by several scholars. ${ }^{11}$

Humanity is at the forefront of Burroughs' writings, especially in ways that change and challenge the limits of humanity, such as mutants, language, social control, disease, parasites, alien species, and for The Western Lands, a mutated version of Egyptian mythology. As noted by Roberta Fornari, Burroughs uses Egyptian mythology "in order to create a "heterocosmica" in which the beliefs of ancient Egypt in afterlife offer a point of reflection on human history and illusions and a particular view of his existential situation as a human being."12 The question then becomes how we can use Burroughs' writing to think about a "generic humanity" that is inclusive; not to follow Burroughs in all his nihilistic thinking, but to take seriously the tools that come from his writings.

What I propose here would mean to take literature as something that thinks; to take the materiality of literature as a mode of thinking and a thinking that goes beyond the intention of the author. Laruelle has proposed the idea of a so-called philo-fiction that takes art "as its model", so that the artworks "are no longer simply modalities of philosophy but precisely models that have, within philo-fictions, their autonomy via a new relation to philosophical modeling." 13 In this way, the philo-fictions of literature can reach new insights that go beyond philosophy-and critical theory more broadly. Any literary

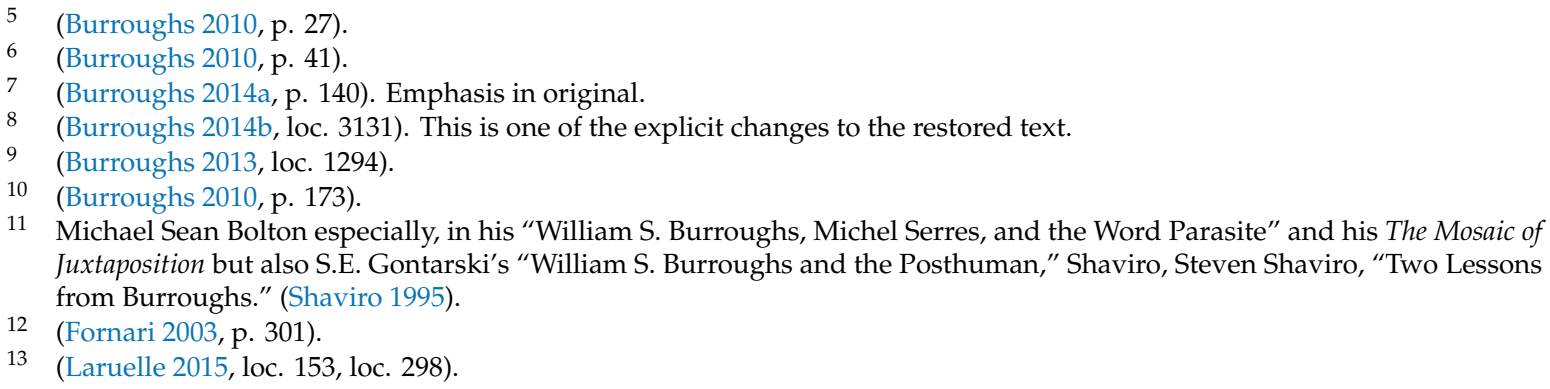


scholar will intuitively agree with Laruelle's claim, even to the point where the concept of philo-fiction may not seem innovative at all—does not all literature make us think? The response here is two-fold. First of all, Laruelle's larger project aims to show that philosophy has guarded its border too well. Only philosophy is what thinks, and inadvertently whatever thinks is philosophy. Laruelle rejects this philosophical imperialism and philo-fictions are a way for him to expand philosophy as something that may also take place outside of philosophy proper (understood as the practice of philosophers).

The second response is that introducing literature as a model goes beyond making literature a modality of philosophy but instead literature retains the autonomy of fiction and allows it to produce precisely that-fictions. A philo-fiction allows for the mutation of thought without care for philosophical propriety or limits. Burroughs' provocation is to make us think of humanity as merely as one-among-many-others. In this respect, we can consider Burroughs as a philosopher who expresses his philosophy through fictional writings rather than academic monographs. This is not an unusual approach and has been pursued by Jones Irwin, who has shown that Burroughs's work "is significantly concerned with philosophical issues". ${ }^{14}$ Irwin pursues social critique and moral issues, but I find Burroughs' writings regarding the human species more potent in relation to ecocritical questions.

Viewing Burroughs as a kind of writer-philosopher also helps with the complicated question of narrator and implied author in most of Burroughs' writings. Extending from The Naked Lunch through to The Western Lands, we often find passages where the line between character, narrator, and implied author blurs. In Naked Lunch, Dr. Benway tells the story of the man who taught his asshole to talk. In a tirade about how the rectum takes over the man and hijacks his eyes, Benway goes off on a tangent about cancer, and how democracy is cancerous with bureaus and bureaucracy. Then follows what can be best described as an extended parenthetical rant: "(It is thought that the virus is a degeneration from more complex life-form. It may at one time have been capable of independent life. Now has fallen to the borderline between living and dead matter. It can exhibit living qualities only in a host, by using the life of another-the renunciation of life itself, a falling towards inorganic, inflexible machine, towards dead matter.)"15 This rant has little connection to the routine that Benway tells, and the use of the parenthesis makes this seem more like an intrusive statement made by the (implied) author.

The Soft Machine has an oft-quoted passage in the chapter "The Mayan Caper": "I cut radio static into the control music and festival recordings together with sound and image track of rebellion. "Cut word lines-Cut music lines-Smash the control images-Smash the control machine-Burn the books—Kill the priests—Kill! Kill! Kill!_" Inexorably as the machine had controlled thought feeling and sensory impressions of the workers, the machine now gave the order to dismantle itself and kill the priests"16 While often read, correctly, in relation to Burroughs' cut-up aesthetics, we again find an intrusive narrator in the lines within the quotation marks. This practice of the intrusive narrator is well-established by the time we reach The Western Lands. One example among many is a narrative of Egyptians discussing what they will encounter in the afterlife. Their rumination is interrupted by a narrator commenting on this bit of narrative: "It is of course assumed by Western savants that the Egyptian animal Gods are the fantasies of a primitive and backward people, who did not have the advantage of the glorious gains of the Industrial Revolution, a revolution in which a standardized human product overthrows himself and replaces his own kind with machines (they are so much more efficient)."17 Although clearly an example of non-diegetic narration, by this point in Burroughs' writings this had become a conventional technique for Burroughs to bring in his own commentary-very often philosophical-political in nature. This is why critics have come to consider these commentaries and intrusions from the "fictional narrator as well as Burroughs-Author" as Anne McDonald phrases it. ${ }^{18}$

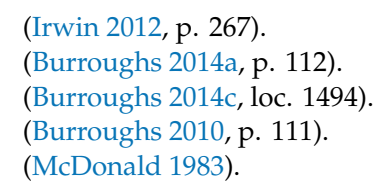


This association of narrator incursions with Burroughs as author is further emphasized by the fact that Burroughs tends to make comments and arguments in his interviews that are largely congruent with these intrusive remarks. In this way, most of Burroughs' writings can very easily be regarded as theory-fictions or philo-fictions. His philosophy is rendered through stylistic and aesthetic techniques, while being especially dependent on intrusive narration. The Western Lands is one of his novels that uses this intrusive narrator device the most. Rather than placing philosophical-political ideas and statements in the words of characters, the Burroughs-author of The Western Lands intrudes incessantly. Rather than the disruptive nature of his cut-up and similar experiments that he used little for the Cities trilogy, the disruption comes from this intrusive narrator-author.

Why do we need art to push beyond philosophy and critical theory in order to think of Homo sapiens otherwise? Because literature is far better at producing alternatives than philosophy; Burroughs' writings constantly challenge the limits of humanity's centrality in the world. That is to say, Burroughs helps us remove the implicit yardstick of "we," especially since this "we" has never been particularly inclusive. Burroughs' acerbic writings refute the cohesion of humanity and instead emphasize its fluidity and changeability, providing an imaginative vocabulary for how to make humanity extinct. Rather than imagining an ecology without nature, as Morton has argued for, Burroughs argues for an ecology without humanity. ${ }^{19}$ We must make humanity extinct in our conception of the world; not that humanity needs to be eradicated but humanity cannot be the central purpose of the world. Burroughs' explicit antihumanism, that admittedly often bleeds into misanthropy, serves as helpful material in this case. Exactly because Burroughs' antihumanism is both an attack on the inhuman behavior of the human species (understood as violence, hatred, and more) as well as an insistence that the human species is a relation, not a thing in itself.

Conceptions of the current climate collapse are always cast in a form where humanity is the central concern: climate collapse disrupts our way of life and we must change it or stop it. As long as we are the measure of the world, things cannot change. Claire Colebrook has shown how the basic assumption for dealing with climate collapse is always cast in terms of "more or less" and that we must "adapt." 20 She phrases this in a Deleuzian manner, saying that we must remove the extensive multiplicities that are determined in advance as equivalences. ${ }^{21}$ This specialized vocabulary simply speaks to the fact that humanity comes pre-defined as the equivalent of the world. The world is for us; it is "our lived world." 22 Climate collapse will then, according to Colebrook, "alter the very unit of 'the human'."23 It well might but it seems more urgent to me to change the unit of the human in order to avoid climate collapse. We cannot wait for external forces to transform us but must do the work of transformation now. Burroughs has a template for how death becomes a positive process, not something to be avoided but something to be sought for. This is not to suggest that Burroughs developed a philosophy for thinking the other-than-human, but it is to suggest that we may use his writings in this manner.

\section{Burroughs and The Extinction of Mankind}

Why use Burroughs' writings as a way to produce a new vision for humanity? Burroughs' writings have often been regarded as antihumanist and misanthropic, and certainly there is truth to such arguments. Chad Weidner notes such misanthropy in Burroughs' novel The Western Lands and in his early cut-ups. ${ }^{24}$ Even as early as 1963, this characteristic feature of Burroughs' works was noted by Thab Hassan. ${ }^{25}$ What can a misanthrope have to tell us about an inclusive, radical humanity? If Burroughs'

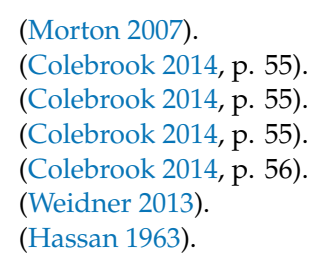


project is one of destruction and "not to order but to shape confusion and to thereby totally discredit the rational world of reality", as Michael Skau has argued, what then can we take from Burroughs in a positive sense? ${ }^{26}$ We can recognize part of Burroughs' anti-humanism as a satiric injunction against humanity's inhuman behaviors. But despite Burroughs' writings often being associated with the satiric tradition from Jonathan Swift and onwards, we may also wish to take Burroughs at face value.

There are at least four ways that Burroughs' writings can be helpful: late-career Burroughs' interest in rewriting the past and the pastoral; writing against epistemologies of certainty; writing as material and method; and the human being as a fluid, non-stable entity. The first way in which Burroughs' writings assist us is outlined by Weidner, who points to the Red Night trilogy (Cities of the Red Night, The Place of Dead Roads, and The Western Lands) as addressing "the unfulfilled potential of nature's nation." ${ }^{27}$ That is to say, only "by reinventing ourselves yet again, we can avoid destruction of the planet." 28 Such a position may seem uncharacteristically optimistic from the writer who gave us Naked Lunch. Nonetheless, as much as The Western Lands in particular delves into death, even on a planetary scale, there are also moments of hope and desire for a future that includes a (different form of) humanity.

Hope, in The Western Lands is a nebulous thing. The novel declares that few will survive, about "one in a million. And, biologically speaking, that's very good odds." 29 These odds crop up a number of times throughout the novel. They tell us two things. First, this is not about individuals but rather a species level. If the human species continues, that is what matters. Secondly, optimism should be measured precisely in the survival of the species. Optimism, then, is not about carrying on as usual but rather that massive changes will occur and that these changes are essentially biological, not social. Of course, we should be cautious about using the word "optimistic" at all in relation to Burroughs, since "The captain says, 'The ship is sinking'. People say he's a pessimist. He says, 'The ship will float indefinitely'. He's an optimist. But this has actually nothing to do with whatever is happening with the leak and the condition of the ship. Both pessimist and optimist are meaningless words." 30 Whatever happens with the human species will not be connected to whether we think it is a good thing or not; it will happen as it happens, whatever the condition of the human species. In other words, pessimist and optimist are anthropocentric words that have no alignment with the case at hand (i.e., human survival).

More than anything, Burroughs' writings attack linguistic certainties and the idea that language can bring us closer together. And yet, his later novels take a different approach to the monolith of language. Skau again: "The reduction of the mass and frequency of the stylistic experimentation in Burroughs' later novels seems to reflect the need to infiltrate rather than to surrender to literary anarchy if verbal tyranny is to be overthrown and a liberated human consciousness is to be achieved." ${ }^{31}$ Despite Burroughs' later writings being less experimental, the aim remains the same: to attack language. But in that attack the aim remains to liberate, not control. A larger take-away from such liberation through infiltration is that we must reject certainty tout court-Burroughs' prose destroys surety and certainty, because such epistemological certainties are indeed control measures. ${ }^{32}$ What Burroughs' writings-even his later ones-teach is that writing and fiction is a crucial tool to understand and conceive of the future.

The third way that Burroughs' writings can help us flows from his attack on epistemological certainties. Writing, whether fiction, history, philosophy, or any other material, is never anything more than raw materials for one's own thinking and should never be sacrosanct. While cut-ups, fold-ins,

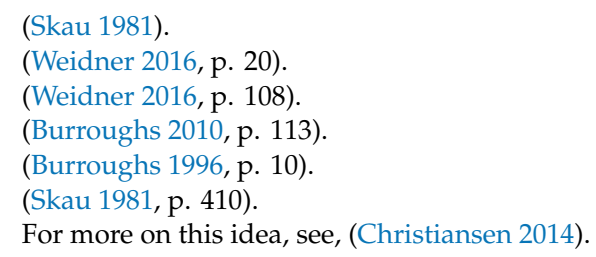


and similar experimental techniques may not lend themselves well to critical thinking, the premise that writing is a method with which to think has resonance with François Laruelle's non-standard philosophy. For Laruelle, we can only understand art if we model our thinking after the art we engage with and that any thinking about art is "about transforming the aesthetic utterances about art and its dimensions". ${ }^{33}$ Our thinking must become a form of art, which, in relation to Burroughs' writings, means precisely rejecting epistemic certainties. ${ }^{34}$ The epistemic certainty that looms the largest is that we know what the human is.

That brings us to the fourth way in which Burroughs' writings can help us rethink mankind and make him extinct: the human being in Burroughs' writings is consistently changeable, malleable, and fluid. In The Western Lands, Joe the Dead is the typical protagonist for Burroughs, who "wasn't there to save human lives. He was there to alter the human equation." ${ }^{35}$ Later, we learn that "We have the advantage. The virus enemy cannot comprehend elasticity. They cannot believe we can survive their seemingly foolproof broadcasts." ${ }^{\prime 36}$ Whatever the human is, it seems that change is part of it. And for Burroughs writing The Western Lands, there is no greater change than the journey to the Western Lands for "it is a journey beyond Death," and "to reach the Western Lands is to achieve freedom from fear." ${ }^{\prime 37}$ The Western Lands are a place of afterlife, the place we go when we die.

To die, or at least to think with Burroughs about extinction, is a fruitful way of thinking the human being anew, because, as Kathryn Hume argues, "instructions of the dead are metaphorically apt as cultural criticism." ${ }^{38}$ But also because Burroughs' writings and writing techniques can achieve that "decisive alienation-effect that can whip us around the repressions death fosters, letting us see anew the magical powers human societies have lodged therein." ${ }^{\prime 39}$ Extinction, death, and the writings about death allow for new thoughts to emerge, through art, and through the art of dying allow us to see humanity differently. That is what Burroughs' writings give us.

\section{To Be Dead}

Burroughs is no stranger to writing about death. His novel The Wild Boys (1971) bears the subtitle A Book of the Dead. Here the reference to death is mostly connect to the rebellious overthrow of society by homosexuals. The Wild Boys is post-apocalyptic, as is several of Burroughs' novels. However, this is not the only interest in death that Burroughs has shown. The peculiar novel-screenplay The Last Words of Dutch Schultz (1970) takes the dying rambles of the infamous American gangster Dutch Shultz (born Arthur Simon Flegenheimer) and spins them into a surreal narrative, most of which is Burroughs' own creation. It would appear that the interest is less in the meaning of Dutch Schultz's words and far more in the surrealism provoked by their strangeness, alongside the notoriety of Schultz himself.

The Western Lands draws on many different sources of inspiration, but a key influence is the Egyptian Book of the Dead and the Tibetan Book of the Dead Bardo Thötröl. The Western Lands is a reference to a destination beyond death, as noted, and it is clear from the novel that death is only the beginning. Death becomes a transformative moment rather than an end; it is a form of precarious freedom from social strictures. This is particularly evident in the vicious attack on Christianity that we find coming from the narrator:

At this point the monolithic One God concept set out to crush a biologic revolution that could have broken down the lines established between the species, thus precipitating unimaginable

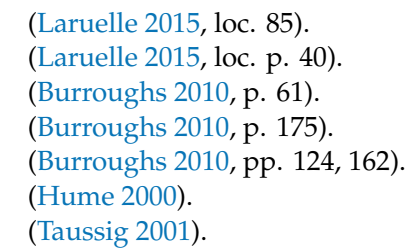


chaos, horror, joy and terror, unknown fears and ecstasies, wild vertigos of extreme experience, immeasurable gain and loss, hideous dead ends. ${ }^{40}$

As is often the case for Burroughs, his narrators often directly intrude with opinions and arguments that we find in Burroughs' expanded oeuvre, such as letters, essays, and other writings. This attack on Western civilization is rather conventional of Burroughs, especially his early writings from Naked Lunch to the Nova trilogy. The Western Lands is mostly a continuation of similar concerns, a rejection of capitalist civilization and authority, as well as organized religion.

Whereas language was the primary enemy in his earlier writings, and attacked with cut-ups and similar techniques, The Western Lands and the Dead Night trilogy of which it is a part are somewhat more conventional. Less cut-up, less extreme in its fragmentation, The Western Lands remains non-linear with large amounts of intrusive narration. This is particularly evident in the extreme switching between deep history (ancient Egyptian), pop culture (Mick Jagger) and future worlds. Such switching is not only head-spinning for the reader but also suggestive of a flattening of time, a kind of plane of temporal equivalence.

This lack of teleology seems countered by the fact that the novel's title is a reference to a place that humanity should attempt to reach; a form of Edenic location and existence. As Frederick Dolan points out, "seeking the Western Lands, then, is an unprecedented project each time it is undertaken and demands above all else a break with common, mainstream ideas of authority, certainty, and utility." 41 Although the journey to the Western Lands is unprecedented each time, breaking away from authority and certainty remains a core component. This view produces a mythic view of this journey to the Western Lands; a quest, something that is larger than the individual human.

Such a view is quite different from the more apocalyptic visions of the Naked Lunch and Nova trilogy; there is, in the novel The Western Lands, a degree of hope and hopeful transformation that is not found in the earlier works. Egyptian mythology becomes a means for this hope, this alternate way of thinking that is used more as raw material than actual anthropological insight. While the hopeful end might be surprising to those familiar with Burroughs, writing oneself out of Western society is a standard practice for Burroughs: "Burroughs often treats the practice of writing oneself out of Western civilization as a preparatory act for a genuine transfiguration of culture and society". ${ }^{42}$ So, Egyptian mythology, and Tibetan, are means of writing oneself out of Western civilization, of attacking Western civilization by introducing or infecting Western civilization with thoughts different from its own. Magic is important for Burroughs in this respect. Not because he necessarily believed in literal magic but because he saw "magic as a means for large-scale transformation of the human Will; indeed, [... ] Burroughs considers it necessary for the transformation of the human species." 43 We can reverse that argument and consider magic anything that transforms the human species. Magic should here be understood in the sense Isabelle Stengers gives it: taking it seriously in order to remove its metaphoric protection, because "the discomfort it creates helps us notice the smoke in our nostrils." 44 In other words, magic becomes an estrangement technique-a provocation to make us think and to give up accepted criteria for the human species or any other aspect that we apply magic to. The purpose of magic is to push back at our conventionalized thinking. Weidner has made much the same argument as Ron Roberts, arguing that

Western Lands suggests that a complex shift in human consciousness may be the only way to allow humans to escape from a ruined planet. The narrative proposes that it is possible to resolve the interminable distance between the ancient Egyptian other and the Amerindian by

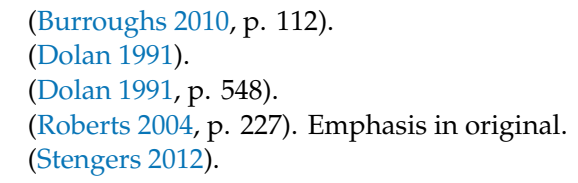


drawing on and consolidating elements from both cultures' mythologies to create a cosmic mysticism for the future. ${ }^{45}$

Mythology, mysticism, and magic become ways to remove and rethink Western conceptions of mankind; to think otherwise than man. Burroughs would certainly consider language magic in this respect, but drugs and other reality-bending practices would also be included in this view of magic. The pastoral elements that Weidner identifies in The Western Lands are similarly part of this rethinking of mankind's relation to the world and the environment. ${ }^{46}$ This is a future mysticism, or magic for the future, a way out of Western civilization. We have to accept reorientation in order to move out of Western civilization, because civilizations essentially work through orienting our perception and our conceptions of the world. Magic is a word which makes us uncomfortable because we are taught that it does not work. But what if it does? What if the power of magic is to open the doors of perception, rather than the closing of these same doors that Burroughs identifies as the actions of an absent-minded writer. ${ }^{47}$ An absent-minded writer is a writer that does not challenge and change the technology that they work with: words. Challenging the technology of writing may be a way to challenge and open up perception, and Burroughs' many experiments with language should be considered in this conception of magic.

This brings us to death. Death in The Western Lands is not an end but a transformative event-in other words, it is a kind of magic. Hume shows that non-Western ideas of death are crucial, because "the borrowed eschatologies do not separate postmortem existence from life in the manner ingrained in Western thought. This continuity creates new ways of reading meaning into life." ${ }^{48}$ These new ways of reading meaning into life can precisely show us life differently. Not solely in the sense of the ambiguous boundary between biological life and death, nor non-Western ideas of the presence of dead ancestors in the present, although surely also these insights. The larger take-away from The Western Lands is a rethinking of the human species that does not proceed from the human species but proceeds instead from the world and the environment.

This bird's eye view of The Western Lands is not an interpretation nor a deep analysis. I have simply located some materials for insight that allow us to see what literature might bring in terms of rethinking mankind. First of all, The Western Lands provide us with a non-linear view of time: ancient history and future are mixed, suggesting a flattening of time or a plane of temporal equivalence. This smashes a teleological view of time and history, which for Burroughs represents a move beyond authority and certainty. We cannot be sure that the future will be better than the past, but what we can try is to think this temporal flattening as a way of avoiding taking Western civilization as the default, simply because it comes after Egyptian (and other) civilizations. "After" is not a meaningful distinction for The Western Lands.

Magic as transformation and transformation as magic is the second insight that The Western Lands provides. This may well be the most challenging aspect of the novel, simply because it is the furthest removed from Western thought. If the old adage "it is easier to think the end of the world than the end of capitalism" is true, then Burroughs challenges us to think, not just of the end of capitalism, but of the end of Western thought and to accept that magic is a real, transformative force in the world. ${ }^{49}$ As lengthy quote from Dolan expresses the stakes quite well:

the writer's task is immense indeed, encompassing a transfiguration of Western perceptions of agency and identity and overturning "responsible" cause-and-effect explanatory narrative through the ecstasy of the synchronous and its logic of displacement. Such a transfiguration,

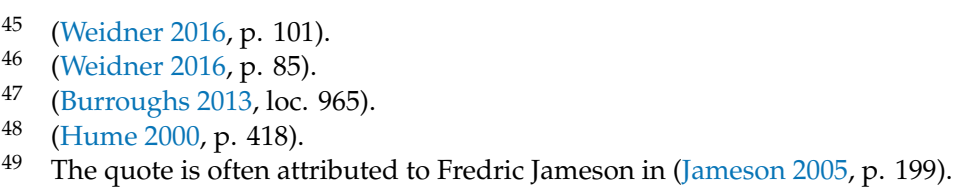


as we have seen, is not only a moral or individual concern but a political one, since it calls into question the character of our shared world and demands the articulation of new criteria for judging the order bequeathed to us by the "Aristotelian" civilization Burroughs rejects, as well as articulating a form of opposition or subversion. ${ }^{50}$

That is what must die. No cause-and-effect narrative, disrupted through the synchronous and displacement; a transfiguration of the entire Western social order and way of thinking; as well as the presentation of new criteria. A tall order, indeed, but then again, it is the planet that is at stake. Death becomes a way of freeing us from a particular way of thinking, of transforming (and transfiguring, this is magic after all) the human species into something other than what we have thought. We must break Morton's loop cycle of a particular kind of humanity inventing itself as the correct model.

\section{No Loops, No Lines}

The Western Lands presents a non-linear conception of time, what I previously called a flattened view of time as a temporal plane of equivalence. Rather than considering time as a teleological movement that proceeds from some deep time to the culmination of the emergence of humanity, time must be seen a continuous shifting that does not have an aim or goal. Burroughs' lack of distinction between ancient past, contemporary present, and imagined future provides an aesthetic experience of what such a temporal conception would be like. Confusing and disorienting, but also exhilarating. It reverses the conventional order of the world, where we have control over the world and instead shows a world that rejects such authority.

Here Burroughs' rejection of authority in toto provides the clue to what needs to happen. The disruptive nature of time in The Western Lands comes mostly through the yoking together of disparate elements. Consider the following, the opening of chapter three: "Neferti is eating breakfast at a long, wooden table with five members of an expedition: English, French, Russian, Austrian, Swedish. They are housed in a large utility shed, with filing cabinets, cots, footlockers, tool shelves and gun racks. The Englishman addresses Neferti: 'Look at you, a burnout astronaut." ${ }^{51}$ Presumably Neferti means Nefertiti, a queen of Egypt and possible pharaoh. Certainly, Nefertiti lived long before there were European nations such as England and France and before astronauts, too. Yet yoking these elements together makes for a strange reading experience that disrespects historical authority.

The Western Lands generally disrespects historical and teleological authority throughout the novel. The narrative structure constantly vacillates between past, present, future, and their intermixing. Sentences like the one quoted above are evident throughout the novel. The same goes for the intrusive narrator, as already mentioned. This intrusion also disrupts the flow of the narrative, as the intrusive narrator comments on events from a different temporal position. Having said that, The Western Lands is far from the most jumbled of Burroughs' works. There is a clear sense of story progression, even if there are many asides and intrusions, and even if temporal linearity is not followed. Compared to the traveling camera narration of The Wild Boys or the run-on sentences of "Johnny 23" in Exterminator! or the more extreme cut-ups of The Nova Express, The Western Lands does come off as more straightforward. Of course, Burroughs was one of the most non-linear, non-teleological, temporally disjunct writers, pushing writing into non-sensical territories at times. That The Western Lands decreases some of that non-linearity and assault on time does not mean that the novel is an easy read, nor does it mean that there is no challenge to temporal unfolding.

In "Johnny 23," for instance, the breaks in time are signaled by ellipses, presumably indicating where the cut was performed. While this makes the text challenging to read, in The Western Lands such disruptions are smoothed over or less jagged. Nefertiti shows up several times, always out of time: "Wilson, the Guide, who lost his license as a White Hunter for shooting rhino with a bazooka, now turns

50 (Dolan 1991, p. 541).

51 (Burroughs 2010, p. 43). 
on Neferti those cold blue eyes that always seem to be looking down a gun barrel." 52 This constant jumbling together of temporally separated events, locations, and people has the effect of dislocating the reader. Yet the device serves a different purpose in The Western Lands than challenging the linearity of writing. Rather, it is the usefulness of time itself that is challenged. In many passages across The Western Lands the intrusive narrator suggests that time is an entirely human concept: "Does time pass if there is no one there to register its passing? Of course not, since Time is a figment of human perception." 53 Time, when capitalized, is associated with the One God and is presented as an oppressive force that forces linearity unto the world.

By jumbling events and people together across conventionalized conceptions of linear time, The Western Lands challenges comprehension differently than the jagged cut-ups of earlier works. Having Nefertiti show up in many different times and locations, including the Kansas City Yards, becomes one of the devices for challenging time. ${ }^{54}$ By challenging our conventional (and Western) conception of time, the novel also implicitly challenges that we have any control over the world. Linearity is a human concept, not a concept that belongs to the world, but, according to The Western Lands, one that we impose on the world around us. The disjunctive devices of The Western Lands become suggestive in terms of rethinking the human species' place in the world-we should not place too much emphasis on a sense of control over the world.

A view of the human species as emerging from the world rather than something over which we have dominion can be connected to Timothy Morton's concept of dark ecology. Morton reluctantly admits that there "is such a thing as the human" but hastens to add that it "need not be something that is ontically given: we can't see it or touch it or designate it as present in some way". ${ }^{55}$ Dark ecology emerges from the fact that the human is a loop formed by our own need to see ourselves as a species. ${ }^{56}$ Morton uses this loop form to show how a particular logistics emerged. He terms this agrilogistics, "an agricultural program so successful that it now dominates agricultural techniques planetwide." 57 Agrilogistics establishes itself, only to loop back and argue that this logic was always already present but also inevitable: "Humans looked back and designated the time of early agrilogistics as a unit, justifying the present" ${ }^{\prime 58}$ This is a feedback loop that produces humanity as a very clearly demarcated thing, with a specific linear history that leads to a given moment-now. For Morton, agrilogistics is what leads to climate collapse; creating the human as that which can control and exploit nature for life.

The problem that we face here is the confluence of natural and human sciences and the way that they are culturally conceived as having a hierarchy. The natural sciences establish certain facts about Homo sapiens that the human sciences must then infuse with meaning and significance. As Colebrook identifies, it is precisely this infusion of meaning and significance that creates a self-perpetuating essence of humanity, "it is man who will read the conditions of this system, discern its proper order, break free from merely instrumental attitudes and arrive at a proper mode of self-regulation." 59 We constantly reinvent ourselves in order to remain the central unit in the world. This is the human species' authority over the human species, and it is that authority which produces a linear history leading to whatever current moment we find ourselves in.

The real magic that Burroughs wants to perform is to break this loop, to not see ourselves as a species that (self-)perpetuates but rather as something that needs to die to become something else. That is to say, we must become extinct in order to survive. Only through a different conception, a different thinking of what the human is, can we hope to continue. Such a logic is a strange loop, but it

\footnotetext{
(Burroughs 2010, p. 91).

(Burroughs 2010, p. 223).

(Burroughs 2010, p. 116).

(Morton 2016, p. 15).

(Morton 2016, p. 160).

(Morton 2016, p. 42).

(Morton 2016, p. 45).

(Colebrook 2014, p. 57).
} 
is the strange loop that Morton identifies and that Burroughs wishes to demolish. The Western Lands is a journey "to create an imaginative pastoral by revealing the potential of a complex mysticism for a future human age." ${ }^{60}$ This complex mysticism centers on the idea of magic as something that can challenge, change, and transform our idea of humanity.

\section{Magic and Animism: Altering the Human Equation}

The interest in The Western Lands is to "alter the human equation." 61 Disease, drugs, violence, myth, death; whatever is at hand may be used to accomplish this goal. Altering the human equation is a way out of the human species authority over the human species, a rejection of Man's authority (the image of humanity as understood quite similarly by Burroughs and Foucault). Disrupting the loop of humanity's self-creation and self-perpetuation is the first step. The second step must be to expand the category of humanity to include a wide variety of Others and Strangers that are generally not considered humans.

Here, I will focus on nonhuman animals, due to Burroughs' interest in dogs and especially cats. However, the point is also to follow Bogna Konior in arguing that anthropomorphism is not human enough. ${ }^{62}$ That is to say, by expanding the idea of personhood beyond narrow conceptions of Homo sapiens, we come closer to what Laruelle and Konior following him conceive as a "generic humanity." As Konior argues, the concept of generic humanity "does away with the desire to capture, represent and project a defined human quality onto nonhumans." ${ }^{\prime 63}$ Two components are important for Konior: a defined human quality and projecting that quality onto nonhumans. We must refuse that there is such a thing as a clearly defined human. This follows Morton's hesitation about the human species and his refusal to claim that such a species has any particular ontic claim. As I argued above, this is because a host of normativities and power relations are built into the expansive claim of homo sapiens as understood by the natural sciences. The confusion of homo sapiens as a biological fact and the understanding that Homo sapiens is necessarily agricultural or sedentary or nomadic or capitalist or red in tooth and claw. These notions are essentially all superstructures built into a biological fact and must be refused. Instead, the human species must be regarded as a relation within a larger part of the world.

Burroughs is right there alongside Konior and Laruelle. As we hear about Joe, one of the protagonists of The Western Lands: "He can't love a human being, because he has no human place to love from. But he can love certain animals, because he has animal places." ${ }^{\prime 64}$ Joe is interested in experimenting and expanding the human species and he does so only using untrained medical personnel, precisely because educated doctors have "absorbed a battery of crippling prejudices." 65 In other words, there is too much of the loop form present in trained doctors. This is not to suggest that doctors should not be trained but rather that Burroughs recognizes that facts and normativities get mixed together and reinforce each other. Normativities must be changed and transformed and the magic of animism can expand social norms in helpful ways-precisely by changing these very norms.

This is Isabella Stengers' argument in her "Reclaiming Animism;" that we must establish a metamorphic and not representational relationship with the world. ${ }^{66}$ This has always been Burroughs' goal and is evident in his many anti-representationist literary practices, whether cut-ups and fold-ins, or simply the flat temporality evidenced in The Western Lands. No doubt magic sits uneasily for most academics, but Stengers makes the use of the word clear: "Protected by the metaphor [of magic],

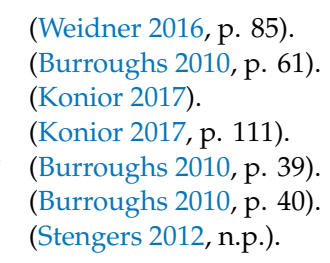


we may then express the experience of an agency that does not belong to us even if it includes us, but an 'us' as it is lured into feeling." 67 This is the idea of generic humanity, a humanity that opens up and includes, rather than closes down and retreats.

Burroughs' use of animals is a good example here. The cat Margaras is described as a powerful being: "the dreaded White Cat, the Tracker, the Hunter, the Killer [ ... ] Having no color he can take all colors. He has a thousand names and a thousand faces. [ ... ] There are those who say we have violated the Articles by invoking Margaras." ${ }^{\prime 68}$ The point here is not the specifics of Margaras but rather that he is described in terms that may as well be a human. Margaras is essentially a person. Magic and metamorphosis is not a question of the supernatural but the acceptance that fiction has power and that no one can "step outside the 'flux of participation'." 69 We are all part of a milieu (Stengers) or an ecology (Morton) or the real (Laruelle) and that whole must be realized as a capacious assemblage. That assemblage is essentially an animist thinking that accepts that "we are not alone in the world" as some form of ultimate apex predator but rather one among many-singular and universal at the same time.

Anthony Paul Smith explicates this notion of simultaneous singular and universal as a duality without synthesis, that the generic is "the individual who has accepted her being universal but limited, who has accepted not being the tip or expression of the absolute" ${ }^{70}$ The lack of synthesis is crucial because that is the transformative moment-that we as individuals are both singular and universal at the same time and that this cannot be reduced to a particular expression. In the same manner, the human species is both singular (a biological fact) and universal (part of the fabric of the world) and we cannot reduce this to a particular relation to the world. The human species does not exist in a relation to the world but is part of the world, inseparable and indistinguishable from the world. Burroughs' refusal to distinguish between human and animal persons help us recognize that.

\section{Death and Extinction}

As we have seen, Burroughs' view of humanity in The Western Lands is not an apogee, but a failed experiment. It should be noted that this does not represent the end of humanity, but the end of humanity as we know it. In other words, Burroughs thinks of extinction as a beginning; if we do not make the human species extinct from our ways of thinking, we will be trapped in within a host of normativities and things will only get worse. Claire Colebrook does something similar in her Death of the Posthuman. Colebrook argues that the problem about humanity is that we have become the yardstick for life, that we have positioned ourselves as "the very figure of life that has rendered the human exemplary of life as such." ${ }^{\prime 71}$ If we push Colebrook's argument to its limit, that means that extinction, as we think it presently, is something that happens to others-all our animal, plant, and other organism others-but never to human life itself. Bostrom's existential risk only includes humans, as if we are the only ones worth worrying about. At its most extreme, if human life is exemplary of life and we are not at risk for going extinct, extinction does not really happen; only less significant forms of life cease to exist. For some transhumanist extremists, such as Elon Musk and Ray Kurzweil, even the collapse of Earth is but a minor impediment to a humanity that will live on Mars or in computers.

What we end up with is a very human version of extinction thought, one that contains and circumscribes extinction as something nonhuman. Colebrook critiques such a view and instead proffers human as parasite as an alternative to human as predator, where the human "lives only in its robbing and destruction of a life that is not its own." ${ }^{72}$. Yet in Colebrook's deconstruction and inversion of

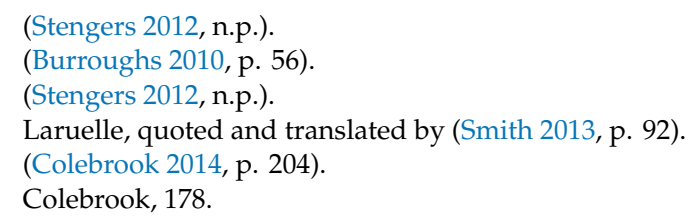


humanity, as useful it is as a theoretical intervention and call for interdisciplinarity, her move retains humanity as a bounded entity, still an exemplar of life, if not a dominant version of life. Certainly, Burroughs has also regarded the human species as a parasite. As Robin Lydenberg showed many years ago, "The internal parasite of received ideas which governs modern myth is anthropomorphized in Naked Lunch as the 'Man Within,' the alien inhuman force which occupies the body and colonizes the will of the addict." 73 Michael Sean Bolton has also explicated how language is the parasite for Burroughs. ${ }^{74}$ Parasite and the human species are tightly integrated for Burroughs, but it is also important to note that the parasite represents the social normativities that oppress the human species. As Bolton points out, various conceptions of the parasite regard it as a crucial image of power relations, including, for Burroughs at times, a productive relation..$^{75}$ Productive, because it leads to alteration and change through noise.

The parasite is external to the human species, even as it interjects and makes itself internal and so disturbs the easy boundaries of life and social power. It is this insidiousness that makes the parasite such a threat for Burroughs, as well as Gilles Deleuze and Michel Foucault, where especially Deleuze derived much of his insight into control societies from Burroughs. Deleuze explicitly references Burroughs for the term control societies: "Control societies are taking over from disciplinary societies. 'Control' is the name proposed by Burroughs to characterize the new monster, and Foucault sees it fast approaching." 76 In this way, we see how Burroughs' writings have already been used as raw material for philosophy. It is also why the parasite is such a useful deconstructive term for Colebrook; arguing that the human species is a parasite rather than a predator reveals the invasive nature of Homo sapiens. At first sight, it also seems to indicate a lesser power relation to the surrounding environment, but as we can see from Lydenberg and Bolton, the parasite is a dominant figure. It is unclear if this is part of Colebrook's use of the term, but since she attempts the minimize the space given to the human in her essays, this is probably unintentional.

Nonetheless, Colebrook's larger argument about extinction is significant because she posits extinction as a thought experiment that suggest that there is only variation, not variation of anything. ${ }^{77}$ That is to say, pushing the logic of extinction to its limit, we cannot (or should not) say that a being, any being, varies in order "to fit a world." ${ }^{\prime 78}$ When there is only variation, variation also applies to the world. For that reason, environment becomes suspect on the base assumption that there is a stable environment to which species beings adapt. The environment is not a stable background against which species (and in this light, as Colebrook has shown, the human species as yardstick) adapt, vanquish, and destroy. The environment itself (as multitudinous assemblages) also adapts—constantly, incessantly—without any care for the human species. In fact, there is no such thing as "the environment" according to Colebrook, but only variation. What we call the environment is only ever an artificially bounded abstraction, but the human species as the yardstick for life has obscured this for us. Because the environment does not resemble us, it does not change or adapt—it stays the same.

Burroughs' focus on fluidity and transformation and, yes, even magic, allows that the world is in constant metamorphosis and that this does not solely apply to the human species, simply because for Burroughs, the human species is not particularly relevant. What controls the human species formed much of his interest, but even that is not limited in The Western Lands to language, his old enemy, but also conceptions of time and life. By refuting any sense of linear or teleological conceptions of time, Burroughs avoids regarding the human species as the pinnacle of anything or the singular goal species

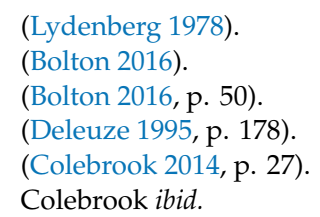


evolution. The human species is headed for extinction, which is the same as transformation in The Western Lands.

As for life, that is a transversal, animist process that does imitate the human species or is singularly human. Most of The Western Lands portrays human beings as constantly changing, dying, or transforming, all on the same level of life as cats, dogs, gods, and other entities. Even cancer is a form of life: "The ultimate purpose of cancer and all virus, is to replace the host. So instead of trying to kill the cancer cells, help them to replicate and to replace host cells." ${ }^{\prime 79}$ Everything is just life, all on the same plane of existence. In other words, life is ecological in Colebrook's sense. Extinct as stable entity but alive as constant variation. This Deleuzian conception of life would see species as finite articulations, plateaus that stabilize for a period of time only to mutate and become something else. Species have their time only to mutate on to something else. My argument here is not that we should accelerate our transformation but to note that the human species is not a static object in the world. As such, our relation is also changeable, and we must face and accept this changeable position.

There is a danger in this valorization of variation. It produces variation as the stable element itself. Such a Heraclitic view of life and nature, where change is the only constant, risks positing change as a positive force. That is not the case, and it is why The Western Lands is a book of the dead. The journey to the Western Lands holds an uncharacteristic amount of hope for Burroughs; that we can somehow move beyond the human impasse and magically transform into something better, possibly more benign. In this way, the theory-fiction of Burroughs posits that there is a way out of the human equation. Through his writing's engagement with time, animism, and extinction, we can see what this way out looks like. It is through a generic, which is to say broadened, humanity that exists as part of a larger, more inclusive world. Because there can be no separation between the human species and the world of which it is part, we cannot limit life to the human species, nor accept that the human species stands as a form of apex atop any kind of hierarchy. That conception of the human species must die and transform into something else.

We must allow for the emergence of the specific against the overdetermination of the human species. ${ }^{80}$ That is to say, we must make extinct the idea that we can define the human species as anything other than a singular and universal relation to the world without performing a synthesis that would stabilize this relation. There is no human species apart from the world, and any definition of the human species would stabilize world-human relations and (re)introduce the human equation. The Western Lands allows us to think outside of the human equation and is not as focused on destruction as Burroughs' earlier writings. Instead, The Western Lands gives us tools for thinking through a transformation. This is the work that this novel does for us as ecocritics; it provides tools for transforming the ways we think of the human. In a way, this is to take one of Burroughs' most famous claims and turning it in its head. If language is a virus, we can use that virus to change our thinking.

Is transformation of the human species an ethical good that we should pursue? In a sense, this is the wrong question, because it extends from an anthropocentric perspective of human exceptionalism. What does need to happen is the recognition that the human species does not and cannot stand apart from a broader ecology. There is not the world and the human as two distinct entities. Even a world-human relation is misleading; better to understand ecological humanity as $h \mathrm{w} u \mathrm{omral} n \mathrm{~d}-\mathrm{co}-\mathrm{mingled}$, inseparable, part of the same equation. That is a deeply ecological message, while it is also one that resists easy conceptualization (as the ugly typographical expression testifies to). The future of extinction is not the extinction of the human species, or so this article hopes. It is the extinction of thinking that the survival of the bee is of little significance to us, unless we eat honey; that COVID-19 is of no significance to us if we are healthy; that the polar ice caps melting only concerns those living below the water line; and so on. We can consider this form of thinking as its own kind of

79 (Burroughs 2010, p. 60).

80 (Konior 2017, p. 116). 
magical thinking. Magical in the sense that it produces a sense of human exceptionalism; that we are somehow a species that stands above other forms of life. Burroughs, as I hope is evident, holds no such illusions. While much of his own views of life were deplorably misanthropic and misogynistic, we need not follow him there. What is useful about Burroughs' writings is his rejection of what conventionally ground human assumptions and conceptions. By rejecting not only the human species as anything other than a relation within a larger ecology, rejecting teleology, embracing magic as a practice of thinking differently, and accepting a world of animism as a way of making the human species unexceptional, Burroughs has furnished us with tools that are eminently suitable for the twenty-first century and for the Anthropocene.

Funding: This research received no external funding.

Conflicts of Interest: The authors declare no conflict of interest

\section{References}

Bolton, Michael Sean. 2016. William S. Burroughs, Michel Serres, and the Word Parasite. Journal of Beat Studies 4: 1. Bostrom, Nick. 2009. The Future of Humanity. In New Waves in Philosophy of Technology. Edited by Jan-Kyrre Berg Olsen, Evan Selinger and Søren Riis. London: Palgrave Macmillan.

Bostrom, Nick. 2013. Existential Risk Prevention as Global Priority. Global Policy 4: 1. [CrossRef]

Burroughs, William S. 1993. May 1, 1950, Allen Ginsberg. In The Letters of William S. Burroughs: 1945-1959. Edited by Oliver Harris. New York: Penguin Books.

Burroughs, William S. 1996. On Writing. In With William Burroughs: From the Bunker. Edited by Victor Bockris. New York: St. Martin's Press.

Burroughs, William S. 2010. The Western Lands. London: Penguin Classics.

Burroughs, William S. 2013. The Adding Machine: Selected Essays. New York: Grove Press.

Burroughs, William S. 2014a. Naked Lunch: The Restored Text. New York: Penguin Books.

Burroughs, William S. 2014b. The Ticket That Exploded. New York: Penguin Books.

Burroughs, William S. 2014c. The Soft Machine. New York: Penguin Books.

Christiansen, Steen Ledet. 2014. Biopoetics of Control and Resistance in William Burroughs' The Nova Trilogy. Prospero XIX: 165-84. [CrossRef]

Colebrook, Claire. 2014. Death of the PostHuman: Essays on Extinction. London: Open Humanities Press, vol. 1.

Deleuze, Gilles. 1995. Negotiations, 1972-1990. Translated by Martin Joughin. New York: Columbia University Press.

Dolan, Frederick M. 1991. The Poetics of Postmodern Subversion: The Politics of Writing in William S. Burroughs's The Western Lands. Contemporary Literature 32: 534-51. [CrossRef]

Fornari, Roberta. 2003. William S. Burroughs' The Western Lands. In America and the Mediterranean. Edited by Massimo Bacigalupi and Pierangelo Castagneto. Torino: OTTO.

Hassan, Ihab. 1963. The Subtracting Machine: The Work of William Burroughs. Critique: Studies in Contemporary Fiction 6: 4-23. [CrossRef]

Hume, Kathryn. 2000. Books of the Dead: Postmortem Politics in Novels by Mailer, Burroughs, Acker, and Pynchon. Modern Philology 97: 418. [CrossRef]

Irwin, Jones. 2012. William Burroughs as Philosopher: From Beat Morality to Third Worldism to Continental Theory. In The Philosophy of the Beats. Edited by Sharin N. Elkholy. Lexington: University of Kentucky Press.

Jameson, Fredric. 2005. Archaeologies of the Future: The Desire Called Utopia and other Science Fictions. London: Verso.

Konior, Bogna. 2017. Generic Humanity: Interspecies Technologies, Climate Change \& Non-standard Animism. Transformations 30: 111.

Laruelle, François. 2015. Photo-Fiction, a Non-standard Aesthetics. Minneapolis: University of Minnesota Press.

Lydenberg, Robin. 1978. Cut-up: Negative Poetics in William Burroughs and Roland Barthes. Comparative Literature Studies 15: 418.

McDonald, Anne. 1983. William Burroughs: Subversion of the Word Machine. Sydney Studies in Society and Culture 1: 196.

Morton, Timothy. 2007. Ecology Without Nature: Rethinking Environmental Aesthetics. Cambridge: Harvard University Press.

Morton, Timothy. 2016. Dark Ecology: For a Logic of Future Coexistence. New York: Columbia University Press. 
Roberts, Ron. 2004. The High Priest and the Great Beast at The Place of Dead Roads. In Retaking the Universe: William S. Burroughs in the Age of Globalization. Edited by Davis Schneiderman and Philip Walsh. London: Pluto Press, pp. 225-40.

Shaviro, Steven. 1995. Two lessons from Burroughs. In Posthuman Bodies. Edited by Judith Halberstam and Ira Livingston. Bloomington: Indiana University Press, pp. 38-54.

Skau, Michael. 1981. The Central Verbal System: The Prose of William Burroughs. Style 15: 401-14.

Smith, Anthony Paul. 2013. A Non-Philosophical Theory of Nature: Ecologies of Thought. New York: Palgrave MacMillan. Stengers, Isabel. 2012. Reclaiming Animism. e-flux, 36. Available online: https://www.e-flux.com/journal/36/61245/ reclaiming-animism/ (accessed on 25 November 2020).

Taussig, Michael. 2001. Dying is an art, like everything else. Critical Inquiry 28: 308. [CrossRef]

Weidner, Chad. 2013. Mutable Forms: The Proto-Ecology of William Burroughs' Early Cut-Ups. Comparative American Studies: An International Journal 11: 314-26. [CrossRef]

Weidner, Chad. 2016. The Green Ghost: William Burroughs and the Ecological Mind. Carbondale: Southern Illinois University Press.

Publisher's Note: MDPI stays neutral with regard to jurisdictional claims in published maps and institutional affiliations.

(C) 2020 by the author. Licensee MDPI, Basel, Switzerland. This article is an open access article distributed under the terms and conditions of the Creative Commons Attribution (CC BY) license (http://creativecommons.org/licenses/by/4.0/). 